\title{
Access to Justice in Environmental Matters in the EU: The EU's Difficult Road towards Non-compliance with the Aarhus Convention
}

Citation for published version (APA):

van Wolferen, M., \& Eliantonio, M. (2020). Access to Justice in Environmental Matters in the EU: The EU's Difficult Road towards Non-compliance with the Aarhus Convention. In M. Peeters, \& M. Eliantonio (Eds.), Research Handbook on EU Environmental Law (pp. 148-163). Edward Elgar Publishing. Research Handbooks in European Law series https://doi.org/10.4337/9781788970679.00018

Document status and date:

Published: 01/01/2020

DOI:

10.4337/9781788970679.00018

Document Version:

Publisher's PDF, also known as Version of record

Document license:

Taverne

Please check the document version of this publication:

- A submitted manuscript is the version of the article upon submission and before peer-review. There can be important differences between the submitted version and the official published version of record.

People interested in the research are advised to contact the author for the final version of the publication, or visit the DOI to the publisher's website.

- The final author version and the galley proof are versions of the publication after peer review.

- The final published version features the final layout of the paper including the volume, issue and page numbers.

Link to publication

\footnotetext{
General rights rights.

- You may freely distribute the URL identifying the publication in the public portal. please follow below link for the End User Agreement:

www.umlib.nl/taverne-license

Take down policy

If you believe that this document breaches copyright please contact us at:

repository@maastrichtuniversity.nl

providing details and we will investigate your claim.
}

Copyright and moral rights for the publications made accessible in the public portal are retained by the authors and/or other copyright owners and it is a condition of accessing publications that users recognise and abide by the legal requirements associated with these

- Users may download and print one copy of any publication from the public portal for the purpose of private study or research.

- You may not further distribute the material or use it for any profit-making activity or commercial gain

If the publication is distributed under the terms of Article 25fa of the Dutch Copyright Act, indicated by the "Taverne" license above, 


\section{Access to Justice in Environmental Matters in the EU: The EU's Difficult Road towards Non-compliance with the Aarhus Convention Matthijs van Wolferen and Mariolina Eliantonio}

\section{INTRODUCTION ${ }^{1}$}

Access to justice in the (now) EU has a long and troubled history, ${ }^{2}$ which is exemplified by the problems faced by those pursuing access to justice in environmental matters. ${ }^{3}$ This chapter aims to illustrate how the judicial organisation of the EU offers an additional challenge to public interest litigants, where there is already a high bar for the 'normal' natural and legal person who seeks to have her day in the golden buildings on top the Kirchberg in Luxembourg. ${ }^{4}$ To that end, the following path through the woods is proposed.

First, a very brief overview of the system of access to justice as it has developed from the Treaty of Rome until now is given. It will be demonstrated what is meant when the Court of Justice of the European Union (CJEU) makes use of its famous tenet that there exists within the EU 'a complete system of remedies'.

Building on that knowledge, it is possible to see the relevance of two recent developments in the European legal order. One entails the changes in the Treaty of Lisbon, mainly in the primary article governing the possibility for judicial review of acts of the EU, and secondary legislation that aims to support these changes. The second is the current line that the CJEU is taking in its case law. Both of these developments need to be placed in

1 The authors wish to thank Helle Tegner Anker for her valuable comments.

2 A by no means complete overview of commentary through the recent decades, Ami Barav, 'Direct and Individual Concern: An Almost Insurmountable Barrier to the Admissibility of Individual Appeal to the EEC Court' (1974) 11 CMLRev 191; Hjalte Rasmussen, 'Why Is Article 173 Interpreted against Private Plaintiffs?' (1980) 5 ELRev 112; Anthony Arnull, 'Private Applicants and the Action for Annulment Under Article 173 of the EC Treaty' (1995) 32 CMLRev 7; Laurence Gormley, 'Judicial Review in EC and EU Law-Some Architectural Malfunctions and Design Improvements?' (2001) 4 CYBELS 167; Albertina Albors-Llorens, 'The Standing of Private Parties to Challenge Community Measures: Has the European Court Missed the Boat?' (2003) 62 CLJ 77.

3 Ludwig Krämer, 'Public Interest Litigation in Environmental Matters before European Courts' (1996) 8 JEL 1; Hans Micklitz, 'The Interest In Public Interest Litigation' in Hans Micklitz and Norbert Reich (eds), Public Interest Litigation Before European Courts, vol 2 (Nomos 1996); Albertina Albors-Llorens, 'Locus Standi of Private Parties in Environmental Cases' (1999) 58 CLJ 1; Laurence Gormley, 'Public Interest Litigation in Community Law' (2001) 7 EPL 51; Jonas Ebbesson, Access to Justice in Environmental Matters in the EU, vol 3 (Kluwer Law International 2002).

4 The Kirchberg is the plateau in the fairy-tale kingdom of Luxembourg upon which the Court of Justice has its domicile. See, famously, Eric Stein 'Lawyers, Judges and the making of a Transnational Constitution' (1981) AJIL 75, 2-27. 
the context of the entry into force of the Aarhus Convention, and the struggles of the EU to comply with its obligations in relation to this third pillar. For this discussion, this chapter will mainly focus on the relationship between the EU and Article 9(3) of the Aarhus Convention. Where the other paragraphs of that Article cause fewer difficulties, the implementation of the third one has been the most problematic, and thus deserving our full attention.

We will end by describing the status quo, which will show that the line of the EU and its courts that judicial protection of the environment will mostly take place at the national level, remains fundamental yet controversial. We will conclude by addressing the pressure that this places on national legal orders and explain how the complexity of implementation of environmental measures equally hinders access to justice for ENGOs in the EU.

\section{ACCESS TO JUSTICE IN THE EU}

Traditionally, the CJEU holds that the system of judicial protection, no matter the interest or party concerned, consists of a complete system of remedies. This means that, according to the Court, the Treaty provides for remedies against all acts of the EU and its institutions, and there will be no possible means by which any act will be able to exist without being open to review by the Court. ${ }^{5}$ The layered nature of the EU provides for two ways of recourse to potential applicants seeking judicial review.

There is a direct route, with a clear role for the Court as the direct adjudicator of conflicts arising by acts of the EU and its institutions, through the existence of (now) Article 263 TFEU. Congruously, there is an indirect route beginning at a national level, as both the Treaty and the case law of the Court envision a role for national courts acting as European courts to request the review of these same acts, should they find a problem in their legality when they are being implemented at the national level. ${ }^{6}$ This last route is possible due to the system created by (now) Article 267 TFEU, the preliminary reference procedure, which allows for national courts to request the CJEU for the review of EU law. ${ }^{7}$

The discussion on access to justice for public interest litigants, especially the ENGOs of interest for the current discussion, has traditionally focussed on the interpretation that

5 Case 294/83 Parti écologiste 'Les Verts' v. European Parliament ECLI:EU:C:1986:166.

6 Roberto Baratta, 'National Courts as Guardians and Ordinary Courts of EU Law: Opinion 1/09 of the ECJ' (2011) 38 LIEI 297.

7 There is a large body of work on this issue, yet the following contributions offer an overview, Ami Barav, 'Some Aspects of the Preliminary Rulings Procedure in EEC Law' (1977) 2 ELRev 3; Carmen Martínez Capdevila, 'The Action for Annulment, the Preliminary Reference on Validity and the Plea of Illegality: Complementary or Alternative Means?' (2006) 25 YEL 451; Gareth Davies, 'The Division of Powers Between the European Court of Justice and National Courts: A Critical Look at Interpretation and Application in the Preliminary Reference Procedure' in Niamh Nic Shuibhne (ed), Regulating the Internal Market (Edward Elgar 2006); The standard work remains M P Broberg and N Fenger, Preliminary References to the European Court of Justice (OUP 2010); Whether this dialogue is effective is debatable, see Sanja Bogojević, 'Judicial Dialogue Unpacked: Twenty Years of Preliminary References on Environmental Matters Initiated by the Swedish Judiciary' (2017) 29 JEL 263. 
the CJEU has given to Article 263 TFEU and the role it sees for the preliminary reference procedure.

In principle, the action for annulment allows natural and legal persons to challenge acts of the EU's bodies and institutions. Although the article was originally more limited in scope regarding the categories of acts that could be challenged ${ }^{8}$ subsequent Treaty revisions have constitutionalised the case law of the Court, whereby in principle any act which is capable of producing a legal effect is open to review. The academic discussion has however primarily revolved around the Court's interpretation of the standing requirements that exist for these natural and legal persons. The Treaty, in its 60 years of existence, has always required natural and legal persons to demonstrate that they are directly and individually concerned by an act, where they seek to have it reviewed by the Court of Justice and the act is not addressed to them.

In the famous 1963 Plaumann case, the Court came to the conclusion that this meant that:

Persons other than those to whom a decision is addressed may only claim to be individually concerned if that decision affects them by reason of certain attributes which are peculiar to them or by reason of circumstances in which they are differentiated from all other persons and by virtue of these factors distinguishes them individually just as in the case of the person addressed. ${ }^{9}$

This definition of 'individual concern' has, in general, been much maligned over the years ${ }^{10}$ however, with the rise of the environment as an area of European legislative competence, it became clear that there is a specific problem when this criterion is applied to environmental litigants. ${ }^{11}$

The definition of individual concern as supplied by the Court of Justice requires a party to be uniquely affected by an act of the EU or its institutions. This is in part logical from a historical perspective, where the mostly economic measures of the Commission, or harmonising legislation, should not be easily set aside through the acts of purely financially motivated economic operators. As such, the Court made it clear in Plaumann that the fact that the number of clementine importers in Germany was known at the time, this did not mean that these importers were all individually concerned. However, when it comes to the environment, an ENGO will never be able to show that it possesses the specific characteristics demanded of the Court to be granted standing, as it will in most cases request the review of an act that cannot be individualised, but rather of acts that affect us all.

This became clear in the Greenpeace case, where the ENGO's request for the review of the decision to supplement funding of the construction of a coal-fuelled power plant on

8 Compare Article 173 EEC 'Any natural or legal person may, under the same conditions, appeal against a decision addressed to him or against a decision which, although in the form of a regulation or a decision addressed to another person, is of direct and specific concern to him.' to the current use of 'act' in Article 263 TFEU.

9 Case 25/62 Plaumann \& Co v. Commission ECLI:EU:C:1963:17.

10 Early on, Barav wrote about the problems of this term. Barav, o.c. However, it was already foreshadowed in the Opinion of Mr Lagrange, in Joined Cases 16 and 17/62 Producteurs de Fruits v. Council ECLI:EU:C:1962:47.

11 See, for an early appraisal, Andrew Geddes, 'Locus Standi and EEC Environmental Measures' (1992) 4 JEL 29. 
the Canary Islands was denied by the Court, as Greenpeace could not demonstrate that it had an interest in the case that could distinguish it from any other inhabitant of the islands. ${ }^{12}$ Although the reasoning of the Court on the relationship between the funding decision and the applicants is logical, the reasoning applied to locus standi of a public interest litigant such as Greenpeace is problematic. Disregarding the nature of the act, the moment an act of the EU has an erga omnes effect, judicial protection will be impossible. This ongoing line of reasoning has meant that, until recently, public interest litigants have only been able to request the review of acts of the EU where they have been granted a specific prerogative or procedural right in, for instance, certain decision-making procedures, which is affected by the contested act. ${ }^{13}$ However, this approach collides with the academic opinion that public interest litigation has been proven to be of great interest to ensure a general check on the rule of law, ${ }^{14}$ and is one of the few successful ways in which the common good can defend itself. ${ }^{15}$ Especially environmental interest organisations and their academic supporters see in public interest litigation a logical and necessary check on how the state uses its powers, ${ }^{16}$ particularly if economic or political interests are preferred above (environmental) public interest. ${ }^{17}$

The outcome of the debate briefly indicated above, has led to most modern legal systems giving the possibility to some form of public interest litigation. ${ }^{18}$ It can therefore seem strange, or at least outdated, that the Court has taken such a strict approach in interpreting this specific clause. However, through the continued challenges of natural and

12 Case C-321/95 P Stichting Greenpeace Council (Greenpeace International) and Others v. Commission ECLI:EU:C:1998:153, on appeal from an Order of the CFI in Case T-585/93 Stichting Greenpeace Council (Greenpeace International) and Others v. Commission ECLI:EU:T:1995:147. The facts of the case complicate the discussion and it should be kept in mind that the Court evaluated the relationship between any citizens of the island and the funding decision of the Commission under the Funding for Regional Development system. The Court explicitly made reference to the fact that the decision to build the power plant was of a national nature and there should be a system of (democratic) control of that decision, but it was not for the Court in this particular case to create it.

13 Case C-355/08 P WWF-UK v. Council ECLI:EU:C:2009:286.

14 David Feldman, 'Democracy, the Rule of Law and Judicial Review' (1990) 19 Federal Law Review 1.

15 Carol Harlow, 'Public Law and Popular Justice' (2002) 65 MLR 1.

16 Ludwig Krämer, 'The Environmental Complaint in EU Law' (2009) 6 JEEPL 13; Ludwig Krämer, 'Public Interest Litigation in Environmental Matters Before European Courts' (1996) JEL 1; Teall Crossen and Veronique Niessen, 'NGO Standing in the European Court of Justice-Does the Aarhus Regulation Open the Door?' (2007) 16 RECIEL 332; Nicolas de Sadeleer, Gerhard Roller and Miriam Dross, Access to Justice in Environmental Matters and the Role of NGOs: Empirical Findings and Legal Appraisal (ELP 2005).

17 However, this discussion is very much influenced by the legal culture that has developed in a state. Van Wolferen demonstrates how any discussion on public interest litigation needs to take place with full knowledge of the developments that have led to the evolution of a court's jurisdiction to hear these cases. See, 'The Limits to the CJEU's Interpretation of Locus Standi, a Theoretical Framework' (2016) 12 JCER 1, 915-30.

18 See for instance the rapport prepared by Eliantonio and others, 'Standing up for Your Right(s) in Europe' (Directorate General for Internal Policies - Policy Department C: Citizens' Rights and Constitutional Affairs 2012) Study PE 462.478 http://www.europarl.europa.eu/RegData/etudes/ etudes/join/2012/462478/IPOL-JURI_ET(2012)462478_EN.pdf, last accessed 28 February 2020. 
legal persons of the Plaumann doctrine, the Court has set out its vision on this system. In this vision, it is believed that those acts that cannot be challenged directly, will have the opportunity to be reviewed through a preliminary reference, as these acts will have an implementation in national law. This stance led to the famous exchange between the (then) Court of First Instance (CFI), the Court of Justice and its Advocate General, Francis Jacobs. In the series of cases $U P A^{19} /$ Jégo-Queré $^{20}$ the challenge by the $\mathrm{AG}$ in his Opinion in $U P A$, as approved by the CFI for a more relaxed approach to individual concern in Jégo-Quéré, was rebuffed by the Court. Jacobs famously set out the problems in relying on preliminary references from national courts to address issues of European law, as it was too dependent on the willingness and ability of a national court to refer, could potentially take a lot of time to resolve the issue as litigants are not certain of a reference in the first instance, and the possibility of even starting litigation depended on there being an actual national measure to contest. In the end, he concluded that the preliminary reference procedure could not be seen as a remedy. Yet, even though in the case of Jégo-Quéré, the Court's standard approach would leave the applicant without a remedy as there was no apparent necessity for implementation in the national legal order, this was not a fault of the system created by the Treaties. Rather, the Court once again placed the onus of securing access to justice on the Member States under the guise of the obligation to give full effect to EU law. ${ }^{21}$

This long running back-and-forth on the functioning of the system of judicial review had an influence on the Intergovernmental Conference on the Constitution for Europe, ${ }^{22}$ that took place in 2003 and 2004. ${ }^{23}$ It led to a so-called Discussion Circle being devoted to the Court and its operation. During the discussion therein, multiple options were discussed for solving the problems with (then) Article $230 \mathrm{EC},{ }^{24}$ including

19 Case C-50/00 P Unión de Pequeños Agricultores v. Council, Opinion ECLI:EU:C:2002:197, Judgment ECLI:EU:C:2002:462. The case dealt with the rights of an association of olive growers to appeal the revocation of a Regulation awarding subsidies for olive oil. As there was no national implementing measure, the olive growers argued they would be left without a legal recourse should they be denied standing under the interpretation of 'individual concern' in Plaumann.

20 Case T-177/01 Jégo-Quéré et Cie SA v. Commission ECLI:EU:T:2002:112, on appeal, Case C-263/02 P Commission v. Jégo-Quéré et Cie SA ECLI:EU:C:2004:210. Similar to UPA mentioned above, although in this case the fishermen argued that the only way in which they could start a case at a national level, was if they were to infringe the Commission Regulation, thus incurring a fine in their Member State, which they then could appeal.

21 See, for an in-depth analysis of these cases, Mariolina Eliantonio and Nelly Stratieva, 'From Plaumann, through UPA and Jégo-Quéré, to the Lisbon Treaty: The Locus Standi of Private Applicants under Article 230(4) EC Through a Political Lens.' [2009] Maastricht Faculty of Law Working Paper 1.

22 See Working Document 21 'Voorstellen voor het waarborgen van een efficiente en effectieve werkwijze van het Hof van Justitie en het Gerecht van Eerste Aanleg' which under point 2 states (trans.): 'The protection of fundamental rights regarding this issue is already safeguarded by the Court of Justice, national courts and the European Court of Human Rights.'

23 See the documentation archived at http://european-convention.europa.eu/ last accessed 28 February 2020.

24 Circle I: Working Document 1 'Access to the Court of Justice for individuals - possible amendments to Article 230, paragraph 4, of the EC Treaty' (26 February 2003) Archived: http:// european-convention.europa.eu/docs/wdcir1/8563.pdf, last accessed 28 February 2020. 
the suggestion offered by AG Jacobs in his UPA Opinion. ${ }^{25}$ However, from the reports made of the sessions of the Discussion Circle, it is clear that any change to Article 230 EC to increase access to justice for public interest organisations was met with strong resistance from both representatives of the Member States and members of the Court. ${ }^{26}$ It was thought that wider access to the Court would increase the chance of spurious litigation. The one problem that the Discussion Circle did see, was the fact that due to the increasing complexity of European decision-making and the instruments used therein, there now existed a category of acts by the EU that could not trigger the road to a preliminary reference, as they do not need to be implemented, nor could they lead to an Article 263 TFEU procedure as they were of a general and abstract nature. ${ }^{27}$ Therefore, Article III-365 Constitution, which is the verbatim predecessor to Article 263 TFEU, included a new category of acts that can trigger direct judicial review by the Court of Justice. ${ }^{28}$

These were 'regulatory acts which are of direct concern and do not require implementing measures', hitherto unknown creatures in the European legal order. ${ }^{29}$ Yet, following the logic of the Discussion Circle, it is clear that these acts are similar to the mesh-size Regulation that lay at the origin of the Jégo-Quéré case. As a result, the Court of Justice has interpreted this clause in line with its general case law on the complete system of remedies. Therefore, the regulatory act has been successfully invoked in cases where agencies or the Commission have set technical standards or similar, in the words of the Court in the defining Microban case, ${ }^{30}$ acts of general application that do not require implementing measures. ${ }^{31}$ The moment there is a possibility of a connection to the national legal order, ${ }^{32}$

25 See, CONV 636/03 p. 7. It should be noted that the approach was slightly different from the one suggested by Jacobs, which read: 'I conclude that an individual should be regarded as individually concerned [. . . [if] by reason of his particular circumstances, the measure has, or is liable to have, a substantial adverse effect on his interests.'

26 See CONV 572/03, p 4 where former president Rodríguez Iglesias argued for a more cautious approach that would lead to the current wording of Article 263 TFEU, see further n. 21.

27 See the final report by Circle I: CONV 636/03.

28 Now to be found in Article 263(4) TFEU.

29 A study into the system of decision-making under the Constitution shows it would have been only slightly more clear in that system, see Jean-Claude Piris, The Constitution for Europe: A Legal Analysis (CUP 2006).

30 Case T-262/10 Microban International Ltd. v. Commission ECLI:EU:T:2011:623, confirmed in Case C-583/11 P Inuit Tapiriit Kanatami and Others v. Parliament and Council ECLI:EU:C:2013:625. This also applies to implementing measures that have not been implemented yet, see Case T-381/11 Eurofer v. Commission ECLI:EU:T:2012:273 where the General Court follows its standard reasoning that for direct concern the distinguishing factor is the discretion of the Member State in implementation, whereas for the definition of an 'implementing act' this is not a consideration, see para 59.

31 Haakon Roer-Eide and Mariolina Eliantonio, 'Meaning of Regulatory Act Explained: Are There Any Significant Improvements for the Standing of Non-Privileged Applicants in Annulment Actions, The' (2013) 14 German LJ 1851; Pieter van Malleghem and Niels Baeten, 'Before the Law Stands a Gatekeeper - Or, What Is a "Regulatory Act" in Article 263(4) TFEU? Inuit Tapiriit Kanatami: Case C-583/11 P, Inuit Tapiriit Kanatami and Others v. Parliament and Council, Judgment of the Court of Justice (Grand Chamber) of 3 October 2013' (2014) 51 CMLRev 1187.

32 Which can be exceedingly tentative, see for instance Case C-456/13 P T \& L Sugars Ltd and Others v. Commission ECLI:EU:C:2015:284. 
the Court will come to the conclusion that the conditions for fulfilling this criterion are not met, ${ }^{33}$ and the procedure should start at a national level. ${ }^{34}$

\section{THE AARHUS CONVENTION AND ACCESS TO JUSTICE}

The EU is a party to the UNECE Convention on Access to Information, Public Participation in Decision-making and Access to Justice in Environmental Matters (Aarhus Convention). ${ }^{35}$ The Aarhus Convention was signed by 34 countries and the European Community in June 1998, entering into force in 2001. It aimed to give effect to Principle 10 of the Rio Declaration, ${ }^{36}$ which in 1992 declared that '[E]nvironmental issues are best handled with the participation of all concerned citizens, at the relevant level'. In essence, Principle 10 acknowledges the fact that although the protection of the environment had become a full-fledged third-generation human right, it is severely hindered by the way in which it can be invoked in national procedures. To that end, the Aarhus Convention aims not to add to the long list of substantive rights that exist in the world, but to create a procedural right for these applicants.

The Convention rests on three pillars of procedural rights, namely the right to be informed on issues with an environmental impact, ${ }^{37}$ the right to participate in the decisionmaking that affects the environment, ${ }^{38}$ and the right to access to justice in environmental matters. ${ }^{39}$ For the purposes of the last pillar, under consideration in this chapter, it is of interest to mention that the Convention assigns a prominent role to non-governmental organisations (NGOs), by providing, in Article 2(5) that these organisations will fall under the definition of 'the public concerned' as being likely to be affected by environmental decision-making or having an interest in proceedings. The Convention follows the line of reasoning set out in regarding public interest litigation, by explicitly calling upon signatories to create a possibility for NGOs to pursue legal avenues in order to defend their (statutory) interests. This is supported by Article 3(4), which calls for each party to the Convention to '[ . . . p provide for appropriate recognition of and support to associations, organizations or groups promoting environmental protection and ensure that its national legal system is consistent with this obligation.'

This automatically leads us to the second point that is of importance in relation to these definitions. Although the Convention aims to secure a basic recognition of ENGOs

33 The distinction here is that the effect on the applicant is through contested act in and of itself, see Case C-552/14 P Canon Europa v. Commission ECLI:ECLI:EU:C:2015:804, para 48.

34 Case T-312/14 Federazione nazionale delle cooperative della pesca et al v. Commission ECLI:EU:T:2015:472.

35 See the 'United Nations Treaty Collection', https://treaties.un.org/doc/Publication/MTDSG/ Volume\%20II/Chapter\%20XXVII/XXVII-13.en.pdf, last accessed 28 February 2020.

36 UNGA Report of The United Nations Conference on Environment and Development (1992) UN Doc A/CONF. 151/26 (Vol. I).

37 Article 4 Aarhus Convention 'Access to Environmental Information'.

38 Article 6 Aarhus Convention 'Public Participation in Decisions on Specific Activities' and Article 7 Aarhus Convention 'Public Participation Concerning Plans, Programmes and Policies Relating to the Environment'.

39 Article 9 Aarhus Convention 'Access to Justice'. 
this does not mean that it aims to harmonise their status amongst the parties to the Convention. As will be demonstrated in discussing Article 9 Aarhus Convention ${ }^{40}$ which sets out the right of access to justice, the precise definition and requirements on what constitutes a NGO remain is still a matter for the parties to the Convention. This is a clear indication of the sensitive nature of the discussion on the role of NGOs in decisionmaking processes and the role they have in the judicial process.

Article 9 defines the Convention's requirements regarding access to justice. The Article follows a tiered approach. The first paragraph relates to gaining access to procedures to defend the right to information, found in Article 4 Aarhus Convention. It provides for the possibility for any person who has attempted to make use of the right to environmental information, as set out in Article 4 Aarhus Convention, to be able to have reviewed before a court or another administrative instance any request that ' $[$. . . ] has been ignored, wrongfully refused, whether in part or in full, inadequately answered, or otherwise not dealt with in accordance with the provisions of that article'.

The second paragraph relates the legal defence of the right of participation in decision-making. Article 9(2) Aarhus Convention starts to build the system of judicial review as envisaged by the drafters of the Convention. Although it too, as with the first paragraph, relates to the judicial defence of a right guaranteed by the Convention, namely Article 6 on Access to Decision-making, the second paragraph sets out a general structure for judicial procedures. It should in this context be kept in mind that the Aarhus Convention does not aim to require Parties to the Convention to adopt a system of actio popularis. ${ }^{41}$ In the defence of the right of members of the public concerned to be involved in decision-making of an environmental nature, Parties may require members of the public concerned to demonstrate either 'sufficient interest' or the 'impairment of a right, where the administrative procedural law of a Party requires this as a precondition'. What constitutes a sufficient interest or an impairment of a right is a matter for the national legal orders of the Parties. The differentiation of these two categories is far from peculiar. They represent the two main systems of ascertaining standing that exist, with the French and English legal tradition making use of the 'sufficient interest' criterion, and the Austro-German school making use of variations on the 'impairment of a right'. The great innovation that the Aarhus Convention aims to achieve is the explicit inclusion of ENGOs in these categories. They are deemed to have a sufficient interest for the purpose of the goals set out in Article 9(2) and they are considered to have rights that can be impaired. Especially the consideration that, according to the article, ENGOs are able to have rights that can be impaired for the purposes of the use of defending their right to participation is ground-breaking.

Although this leaves the Parties sufficient space to keep their distinct systems in place, and does not require every Party to adopt a system of actio popularis, from the ACCC explanations on Article 9 it is clear that the objective of the Convention is to guarantee a wide as possible an access to justice for environmental litigants within the allowed

40 Thirza Moolenaar and Sandra Nóbrega 'Access to Justice: Environmental Non-Governmental Organizations According to the Aarhus Regulation' (2016) ELNI 2, 76-84.

41 However, Jendrośka says it was the original intention of the parties, Jerzy Jendrośka, 'Aarhus Convention and Community Law: The Interplay' (2005) 2 JEEPL 12, 19. 
systems. ${ }^{42}$ The application of the criteria by the national judiciary may mitigate the literal definition given in the law.

The main point of discussion regarding Access to Justice and the Aarhus Convention, especially in the context of EU law, has been Article 9(3). This provision aims to secure a more general right of access to justice for problems of an environmental nature that lie beyond the preceding two paragraphs. Building upon Article 9(2)'s instructions regarding the different possibilities that legal systems will have to choose their system of locus standi, paragraph 3 requires a wider system of judicial protection, not only for specific Aarhus-related rights:

[. . . ] each Party shall ensure that, where they meet the criteria, if any, laid down in its national law, members of the public have access to administrative or judicial procedures to challenge acts and omissions by private persons and public authorities which contravene provisions of its national law relating to the environment.

Given the abstraction of this more general obligation from the other two pillars of the Convention, it is logical that Article 9(3) foresees a wider scope of applicants. ${ }^{43}$ Thus, the right is not limited to the public concerned, but applies to 'the members of the public'. The access that these members of the public are granted can be limited by the criteria that exist in the national legal orders, but should not be so strict as to effectively bar the use of the right. ${ }^{44}$ Restrictions for access to justice have to be reasonable in the light of effective judicial protection, and Parties should use these sparingly given the objectives of the Convention. ${ }^{45}$

Finally, the drive for an open system of (judicial) review of acts affecting the environment and to make that system easily accessible is further supported by Article 9(4) Aarhus Convention, which covers the practical elements relating to access to justice. The article sets out general requirements such as the fact that remedies shall be effective, fair, timely, equitable and not prohibitively expensive. It equally demands that there be a system of injunctive relief available in the legal systems of the Parties, and that records of proceedings should be open to the public.

\section{THE EU AND THE AARHUS CONVENTION}

The EU acceded to the Aarhus Convention by way of Decision 2005/370/EC. ${ }^{46}$ While signing the Aarhus Convention, the EU indicated that the implementation of the principles contained therein was already in progress; however in relation to Access to Justice, the Union remarked that:

In particular, the $[E U]$ also declares that the legal instruments in force do not cover fully the implementation of the obligations resulting from Article 9 (3) of the Convention as they relate

\footnotetext{
42 ACCC/C/2005/11 Belgium.

43 ACCC/2005/11 Belgium; ECE/MP.PP.1/C.1/2006/4, Add.2, 28 July 2006, para 29.

44 Ibid., para 35.

45 Decision II/2.

46 Council Decision 2005/370 OJ L 124/1.
} 
to administrative and judicial procedures to challenge acts and omissions by private persons and public authorities other than the institutions of the [EU] as covered by Article 2 (2)(d) of the Convention, and that, consequently, its Member States are responsible for the performance of these obligations at the time of approval of the Convention by the [EU] and will remain so unless and until the Community, in the exercise of its powers under the [Treaties], adopts provisions of Community law covering the implementation of those obligations. ${ }^{47}$

This statement should be kept in mind, as it is exemplary of the EU's view on access to justice in general in light of the following discussion.

Implementation of the Convention has mostly taken the form of retooling of specific pieces of secondary legislation relating to the environment, such as the Environmental Impact Assessment (EIA) Directive. ${ }^{48}$ As will be discussed in the following paragraph, most of these pieces of secondary legislation find their effect on the national level in the Member States, and do not have any consequences on the regime of access to justice at the EU level. However, the one exception to this is Regulation 1367/2006/EC which aims to secure compliance of the EU with the Aarhus Convention at the level of the EU institutions.

\subsection{Implementation by the EU Aimed at the Member States Level}

Implementation of the Convention has mostly taken its effect on the Member States level. As such, Directive 2003/4/EC repealed the previous Directive on the public's access to environmental information and brought the definition of 'environmental information' in line with the definition in the Convention. ${ }^{49}$ Directive 2003/35/EC implemented the requirements regarding public participation by amending the EIA Directive and the IPPC Directive. In revising the EIA Directive, Directive 2003/35 explicitly added provisions on access to justice for members of the public concerned in order to challenge decisions taken by Member States when acting within the scope of the Directive. The added Article 10a, ${ }^{50}$ mirrors the wording of Article 9(2) of the Aarhus Convention, thereby aiming to fulfil the obligation to provide access to justice in relation to plans and programmes. In general, the transposition of the Directive, and as a result compliance with Article 9(2) Aarhus Convention, has seen few problems. This is in part due to the fact that, as will be demonstrated in the following section, the Court has intervened to interpret preliminary references stemming from Directive 2003/35 in line with the aims and purposes of the Aarhus Convention. ${ }^{51}$

47 'United Nations Treaty Collection, Chapter XXVII Environment, 13. Convention on Access to Information, Public Participation in Decision-Making and Access to Justice in Environmental Matters.', edited to reflect the current situation. https://treaties.un.org/doc/Publication/MTDSG/ Volume\%20II/Chapter\%20XXVII/XXVII-13.en.pdf, last accessed 28 February 2020.

48 Other pieces of legislation have also been drafted with the Aarhus Convention in mind, see: Directive 2004/35/EC on environmental liability with regard to the prevention and remedying of environmental damage [2004] OJ L143/56; or the Water Framework Directive, Directive 2000/60/ EC OJ L327/1.

49 Council Directive 2003/4/EC of 28 January 2003 on public access to environmental [2003] OJ L 41/26, repealing Council Directive 90/313/EEC of 7 June 1990 on the freedom of access to information on the environment [1990] OJ L 158/56.

50 Now Article 11 in Directive 2011/92.

51 Mariolina Eliantonio, 'Collective Redress in Environmental Matters in the EU: A Role Model or a "Problem Child"?' (2014) 41 LIEI 257, s 4. 
A point of contention in relation to implementing the Aarhus Convention has been the failed attempt to adopt a general Directive on Access to Justice in Environmental Matters that would transpose the requirements of Article 9(3) of the Convention. The proposed Directive 2003/624/EC would have set minimum standards for Member States on access to justice for so-called environmental proceedings. ${ }^{52}$ In these environmental proceedings, ${ }^{53}$ the members of the public concerned and 'qualified entities' would be assured legal redress to challenge acts and omissions by both government and private entities, as required by Article 9(3) of the Aarhus Convention. Qualified entities would be the Directive's means to ensure access to justice for a wide diversity of environmental organisations, while allowing Member States the possibility of setting minimum requirements for these organisations, such as membership numbers or specific statutory goals. The Directive ultimately did not make it through the legislative process, as the Commission withdrew the proposal following a ten-year long period of inaction by the Council. ${ }^{54}$ As will be discussed in our epilogue, the only change in the status quo has been the enactment of a rather uneventful Communication on Access to Justice. ${ }^{55}$

\subsection{Implementation by the EU Aimed at the EU Level}

Access to justice is broadly defined by the Convention relating to the entirety of the judicial system in relation to the access to information and decision-making. There is no obligation to create a new system of judicial or administrative review, but the existing system should accommodate the possibility for environmental complaints. However, the European legislator has chosen a more creative approach. Regulation 1367/2006 does not aim to affect the system of remedies as set out by the Treaties. Nor would it ever be able to do so, as secondary legislation is inherently unable to influence the constitutional law of the Treaties. ${ }^{56}$ Thus, the Regulation has created a new form of administrative review, by creating a new category of acts, namely, requests for an internal review of administrative acts. Article 10, explicitly aimed at providing environmental NGOs, when compliant with the conditions set out in Article 11, a manner to secure the administrative review of so-called 'administrative acts'. As we will demonstrate in the following section, the interpretation of the nature of this new category of acts, has caused significant difficulties.

52 COD 2003/0246 Proposal for a Directive of the European Parliament and of the Council on access to justice in environmental matters, 24 October 2003.

53 As explained by the Commission in its proposal: 'The definition (of environmental law in this context) must be consistent with the Århus Convention, taking up the main aspects of the environment.' This largely mirrors the approach of the Court, which has taken liberal interpretation on what defines 'an effect on the environment'; See for instance case C-442/14 Bayer CropScience v. Stichting De Bijenstichting ECLI:EU:C:2016:890 on the definition of environmental information.

54 OJ C 153/3 21 May 2014.

55 C(2017) 2616 final of 28 April 2017 'Commission Notice on Access to Justice in Environmental Matters'.

56 See Case T-236/04 EEB and SNM ECLI:EU:T:2005:426 para 71. 


\section{TWO OPPOSING VIEWS TO ACCESS TO JUSTICE}

ENGOs believed neither the Lisbon Treaty nor the implementation of the Aarhus Convention sufficiently cleared the way to the Court for public interest litigants, even though there was - in their opinion - a clear obligation for the EU to address this possibility under Article 9(3) of the Convention. In a procedure before the Convention's Compliance Committee (ACCC), 14 ENGOs argued that this vision was insufficient to secure access to justice for the environment. ${ }^{57}$ A protracted procedure, spanning the entry into force of the Lisbon Treaty as the EU stated that it would prove its devotion to the Aarhus Convention, pitched the opposing views that have existed since Jacobs expressed his criticism in $2002 . .^{58}$

In the pre-Lisbon phase of the ACCC procedure, it became clear that the ACCC did not believe the EU to sufficiently support public interest litigants, as per their obligation under the Aarhus Convention..$^{59}$ This was due to the fact that the ECJ had denied any possibility for the Aarhus Convention to be relied on directly by Parties, not when the Convention had entered into force, nor when the EU had acceded to it. Although in the Região autónoma dos Açores the Court of First instance had hinted at the fact that the Aarhus Convention could play a role in the revaluation of the assessment of standing of parties, ${ }^{60}$ which in itself was an improvement over the CFI's initial stern rebuke of the possibility of the Convention ever having a direct effect on the European legal order, ${ }^{61}$ the ECJ would always 'correct' the CFI and enforce the traditional line that it would only be the Treaty as interpreted by the Court in Plaumann that set the standing requirements for private applicants, including environmental NGOs. ${ }^{62}$

In the course of the procedure before the ACCC, the EU however pled that the entry into force of the Lisbon Treaty and the Aarhus Regulation would lead to full compliance of the Union to the principles of the Aarhus Convention. The newly created category of 'regulatory acts' would address the lacunae in the complete system of remedies, and the Regulation would cover the administrative acts of lesser importance through administrative review. Based on these promises, the ACCC adjourned the procedure, to be resumed after the outcome of the case of $S N M \& P A N v$. Commission, where the Court would have a chance to check the effect of the Aarhus Regulation. ${ }^{63}$ In the words of the Compliance Committee:

57 The full list can be found in the document on the ACCC website named 'List of NGO supporting the communication' http://www.unece.org/fileadmin/DAM/env/pp/compliance/C2008-32/ communication/SupportingNGOs.pdf, last accessed 28 February 2020.

58 See, n. 18.

59 'Findings and Recommendations of the Compliance Committee with regard to Communication ACCC/C/2008/32 (Part I) Concerning Compliance by the European Union', 14 April 2011.

60 Case T-37/04 Região autónoma dos Açores v. Council ECLI:EU:T:2008:236, paras 92-93.

61 Case T-94/04 European Environmental Bureau (EEB) v. Commission ECLI:EU:T:2005:425 and Case T-236/04 EEB \& SNM v. Commission ECLI:EU:T:2005:426.

62 See for instance the appeal in Case C-444/08 Região autónoma dos Açores v. Council ECLI:EU:C:2009:733.

63 Case T-338/08 Stichting Natuur en Milieu en Pesticide Action Network Europe v. Commission ECLI:EU:T:2012:300. 
While the Committee is not convinced that the Party concerned fails to comply with the Convention, given the evidence before it, it considers that a new direction of the jurisprudence of the EU Courts should be established in order to ensure compliance with the Convention. ${ }^{64}$

It was in the second phase where the exchange between EU and ENGOs got heated. The ENGOs pointed out that the vague promise of change after the first phase had not occurred when the EU was directly challenged on either the invocability of the Aarhus Convention, ${ }^{65}$ or the effect of it on Regulation 1367/2006. ${ }^{66}$ This was becoming especially clear in the case law relating to the functioning of the system of administrative review that the EU had implemented, the so-called 'internal review procedure'. ${ }^{67}$ Although, as mentioned, administrative review is an option under Article 9 of the Aarhus Convention, the ENGOs pointed out that the Court was interpreting the requirements so strictly as to bar access to the procedure, rendering it moot. ${ }^{68}$ It was also only in this second exchange that the ENGOs again raised the point once made by AG Jacobs as set out above. ${ }^{69}$

In the very case on which the ACCC had adjourned the procedure, ${ }^{70}$ the ENGOs challenging the Commission's denial of an internal review pleaded that the definition of 'administrative acts' as interpreted by the Commission was too narrow. In doing so, they relied on the wording of Article 9(3) of the Aarhus Convention, as the Commission unnecessarily limited the definition of 'acts' contained therein, to acts of an individual nature. This, so SNM and PAN Europe claimed, is clearly against the aims and purposes of the Convention. A number of similar cases followed this argumentation. ${ }^{71}$ At first the General Court accepted the reasoning and ordered the Commission to reconsider the denial of the internal review. However, following the reasoning used in cases such as $L Z I,{ }^{72}$ the Court of Justice overturned the General Court's judgments on the basis that Article 9(3) Aarhus Convention was not sufficiently clear and precise to be relied

64 'Findings and Recommendations of the Compliance Committee with Regard to Communication ACCC/C/2008/32 (Part I) Concerning Compliance By The European Union', 27 April 2011, para 93.

65 Case T-91/07 WWF-UK v. Commission ECLI:EU:T:2008:170 paras 71-72.

66 For instance in the Cases C-401 to 403/12 P Council v. Vereniging Milieudefensie \& SNM ECLI:EU:C:2015:4, where the Court dismissed the critical remarks of the General Court on the criterion of 'administrative acts' entailing the need for 'individual scope' in light of Article 9(3) Aarhus Convention, see section 3.1.

67 Jan Jans and Gertjan Harryvan, 'Internal Review of EU Environmental Measures. It's True: Baron Van Munchausen Doesn't Exist! Some Remarks on the Application of the So-Called Aarhus Regulation' (2010) 3 REALaw 53.

68 For instance in the Cases C-401-403/12 P, where after the critical remarks of the General Court on the criterion of 'administrative acts' entailing the need for 'individual scope' in light of Article 9(3) Aarhus Convention (Cases T-338/08 and T-396/09) the ECJ refused to allow the parties to rely on the Aarhus Convention to make the procedure available for interested parties that were not the addressees of the original act.

69 'Pleading notes of ClientEarth to the Aarhus Convention Compliance committee in relation to communication ACCC/C/2008/32 Part II', 1 July 2015.

70 Case T-338/08 ECLI:EU:T:2012:300.

71 At the moment of writing, the Curia database of the Court of Justice lists 23 cases which deal with the definition of the 'administrative act'.

72 Case C-240/09 Lesoochranárske zoskupenie VLK v. Ministerstvo životného prostredia Slovenskej republiky (LZ I) ECLI:EU:C:2011:125. 
upon by a legal person in proceedings. As a result, it has been confirmed by the Court in multiple cases ${ }^{73}$ that the internal review procedure is now in fact only open to individual decisions taken by the Commission against a natural or legal person. ${ }^{74}$ Thus, so reasoned ClientEarth, the hostility of the EU legal order against public interest litigation was again proven.

Interestingly, the Commission, representing the EU, did not directly contest these claims, but rather set out to illustrate how in a series of cases the CJEU had enforced the principles of the Aarhus Convention in the legal orders of the Member States, proving its devotion to the Convention. More importantly, the Commission argued that by enforcing Article 9 Aarhus Convention in the Member State, the Court of Justice had reinforced the system of remedies. This ensures easy access to justice in Member States, requires cost-effective litigation, and ensures early references to the CJEU where an act of the EU was the underlying point of contention. ${ }^{75}$

There is some truth to this statement. Beginning with Djurgården, in which the Court for the first time made use of the Aarhus Convention to interpret the effects of Directive 2003/35 on the EIA Directive, ${ }^{76}$ the Court has actively pushed Member States to comply with the obligations under the Aarhus Convention through EU law. ${ }^{77}$ In traditional areas that hinder access to justice, such as the cost of litigation and access to interim measures, ${ }^{78}$ narrow definitions of the grounds for a procedure ${ }^{79}$ narrow definitions of public authority, ${ }^{80}$ and even the problems surrounding the highly sensitive area of standing requirement, ${ }^{81}$ the CJEU has acted as an enforcer of the Convention. ${ }^{82}$

73 Most recently in Case T-12/17 Mellifera v. Commission ECLI:EU:T:2018:616.

74 See the appeal in C-401/12 P to C-403/12 P Council, Parliament \& Commission v. Vereniging Milieudefensie \& Stichting Stop Luchtverontreiniging Utrecht ECLI:EU:C:2015:4, where the decision of the Commission to allow the Netherlands to make use of an extension, provided for in the Air Quality Directive, was also considered to be of general scope.

75 'Statement by the Commission, on behalf of the EU, in the hearing on 1 July 2015 in Geneva on Case ACCC/C/2008/32', 1 July 2015.

76 Case C-263/08 Djurgården-Lilla Värtans Miljöskyddsförening v. Stockholms kommun genom dess marknämnd ECLI:EU:C:2009:631.

77 See the Court's reasoning on how the Aarhus Convention finds its way in the legal orders of the Member States through the Habitat Directive, Case C-240/09 Lesoochranárske zoskupenie VLK v. Ministerstvo životného prostredia Slovenskej republiky (LZ I) ECLI:EU:C:2011:125.

78 Case C-260/11 Edwards and Pallikaropoulos ECLI:EU:C:2013:221 and Case C-530/11 Commission v. United Kingdom ECLI:EU:C:2014:67

79 Case C-570/13 Karoline Gruber v. Unabhängiger Verwaltungssenat für Kärnten et al. ECLI:EU:C:2015:231.

80 Case C-204/09 Flachglas Torgau GmbH v. Federal Republic of Germany ECLI:EU:C:2012:71; Case C-279/12 Fish Legal \& Emily Shirley v. Information Commissioner, United Utilities Water plc, Yorkshire Water Services Ltd, Southern Water Services Ltd ECLI:EU:C:2013:853 and Case C-644/15 Protect v. Gmünd ECLI:EU:C:2017:987.

81 Case C-115/09 Bund für Umwelt und Naturschutz Deutschland, Landesverband NordrheinWestfalen eV v. Bezirksregierung Arnsberg (BUND) ECLI:EU:C:2011:289, [2011] ECR I-3673.

82 A role that is not uncontroversial, see Jans' amazement at the manner in which the Court reasons it has the possibility to enforce the Aarhus Convention, Jan Jans, 'Who is the Referee? Access to Justice in a Globalised Legal Order' (2011) 4 REALaw 85. 


\section{THE ROAD FORWARD}

After the ACCC had come to the conclusion that the picture painted by the Commission during the proceedings was insufficient to satisfy the EU's obligation under the Convention, some peculiar developments took place. Under the Convention's system, the ACCC helps signatories to comply with the Convention, and any official findings will be declared by the Meeting of Parties (MoP). The MoP is however filled by a majority by EU Member States, who have purposefully crafted the system of remedies in the Treaty of Lisbon, and the EU itself. Thus, for the first time in its existence, the MoP did not follow the findings of the ACCC and did not declare the EU to be in non-compliance. ${ }^{83}$

At the same time, the Commission produced an Interpretative Communication on Access to Justice in Environmental Matters. ${ }^{84}$ Where the ACCC had come to the conclusion that the tiered system of access to justice regarding acts or omissions by the EU and its institutions was insufficient to safeguard the right set out in Article 9 Aarhus Convention, the Communication doubled down on setting out this point of view to the Member States. Beginning by referencing the fact that the Council had failed to undertake any action on the previously mentioned Directive on Access to Justice after ten years, the Commission sets out the obligations on national courts to act as 'ordinary courts' for implementing EU law in the legal systems of the Member States. ${ }^{85}$ It then proceeds, on a point-by point-basis very similar to the failed Directive, to explain the obligations upon the legal orders of the Member States in securing access to justice for environmental litigants, while at the same time cheerleading the achievements of the Court in its judgments and itself for its successful enforcement actions.

The Communication makes it clear that in the eyes of the EU, it is business as usual. In principle the same system remains in place. Direct access to the Court of Justice will only be possible for those natural and legal persons who meet the Plaumann criteria, unless the rare case presents itself that they are contesting the validity of a regulatory act not entailing implementing measures. Even then, the elephant in the room is the fact that the criterion of 'direct concern' has been largely left undeveloped. However, because of the stricter interpretation by the Court of its original meaning (i.e., no intercession in any way by a Member State in the manner in which an act of the EU affects an applicant), it might hamper access to justice for public interest litigants in just as severe a manner as

83 For an account, see Nathalie Berny, 'Failing to Preach by Example? The EU and the Aarhus Convention' (2018) 27 Environmental Politics 757. The formal solution was that the MoP did not come to a decision of non-compliance, but that '[...] the findings of the Compliance Committee should not be "endorsed" but "taken note of", , see the Report of the sixth session of the Meeting of the Parties (Budva, Montenegro, 11-13 September 2017) ECE/ mp.pp/2017/2, 13 .

${ }_{84}$ C(2017) 2616 Final.

85 This was already a part of the case law of the Court, but has now been firmly entrenched in Article 19(2) TEU: 'Member States shall provide remedies sufficient to ensure effective legal protection in the fields covered by Union law.' This has been given a significant boost in importance with the recent Case C-64/16 Associação Sindical dos Juizes Portugueses v. Tribunal de Contas ECLI:EU:C:2018:117, on the obligation of Member States to secure an adequate level of judicial protection. 
Plaumann. ${ }^{86}$ Therefore the logical route for these applicants, when they want to defend the interest of the environment, will be solely through a national procedure. This is not only explicitly mentioned in the case law of the last 30 years since Les Verts and UPA/ Jégo-Quéré, but every single development, from the interpretation of 'regulatory acts' and consequently 'implementing measures' to the case law addressing judicial review in the Member States, to the interpretative notice of the Commission. This is unsatisfactory to those ENGOs who see a crucial role for courts, especially the CJEU given its role as sole interpreter of EU law, in the fight for the protection of the environment. ${ }^{87}$ The CJEU however, sees its role in the judicial system as constrained, and is still unwilling to change its position on Plaumann. ${ }^{88}$ Accordingly, it is for the Masters of the Treaty to enact a change, yet the reader will agree that it is precisely these Masters who do not wish to invite greater scrutiny of their work, which ensures an optimal freedom for Member States to 'balance' environment and economy. As it stands now, Member States through the Council have the possibility to seemingly enact green legislation, which then offers them sufficient wiggle room for allowing (polluting) economic activities at a national level. In the absence of a Marbury v. Madison moment, ${ }^{89}$ this stalemate is not likely to be resolved.

86 The likelihood of this occurring has already been discussed by the authors, see for instance Mariolina Eliantonio's Observation to the second phase of case ACCC/2008/32 (EU) for the Meeting of 1 July 2015 http://www.unece.org/fileadmin/DAM/env/pp/compliance/C2008-32/Fr om_Observer/frObservers_Eliantonio_26.06.2015.pdf, last accessed 28 February 2020 and Matthijs van Wolferen, 'Access to Justice after Lisbon: Slowly Getting to Where You Didn't Want to Be' in Fabian Amtenbrink and others (eds), The Internal Market and the Future of European Integration (CUP 2019).

87 However, it has been strongly argued that this is not the manner in which judicial review should be approached and can lead to a problem of judicial authority, see for instance: Jeremy Waldron, 'The Core of the Case against Judicial Review' (2006) 115 Yale LJ 1346, 1376 on 'outcome-related reasons'.

88 A possible explanation for this position is given in Matthijs van Wolferen, 'To Justifie the Wayes of God to Men' (PhD thesis, University of Groningen 2018).

89 Marbury v. Madison, 5 US (1 Cranch) 137 (1803), in which the Supreme Court of the United States unilaterally interpreted the extent of its original jurisdiction from the vague wording of Article III of the US Constitution. 